\title{
A STUDY TO ASSESS THE EFFECTIVENESS OF INFORMATION BOOKLET ON KNOWLEDGE REGARDING PREMENSTRUAL SYNDROME AMONG SECONDARY SCHOOL GIRLS IN SELECTED RURAL SECONDARY SCHOOL AT UDAIPUR
}

\author{
Geetanjali Sharma \\ Venkteshwar College of Nursing \\ Umarda Udaipur (Rajasthan) \\ Corresponding Email: shrma.geet86@gmail.com
}

\begin{abstract}
Introduction: Menstrual cycles are a key driver of reproductive events in women,which is a physiological process and associated with the ability to reproduce.In the past twenty years premenstrual syndrome (PMS) has emerged as a well-recognized phenomenon for which effective effective treatments are available.Unfortunately,because of the widespread public awareness of adverse premenstrual experiences,most women mistakenly believe that they have PMS.
\end{abstract}

Material and Methods: The method adopted for the present study was evaluative approach as the study aimed at development of an intervention for assessing the knowledge of 120 secondary school girls in government secondary School dakan kotda at Udaipur this approach would help the investigator to evaluate the effect of specific interventions that is information booklet on the variable that is knowledge of secondary school girls regarding premenstrual syndrome in selected school at Udaipur in this study samples were drawn by using simple random sampling method data was collected by using structured knowledge questionnaire.

Results: The pretest knowledge score is taken for finding the association between pre test knowledge with selected demographic variable of secondary school girls the chi square value of demographic variables such as age in years, class, religion, educational status of the mother, source of information, age at menarche, interval of menstruation, Do you experienced premenstrual syndrome were not significant at 0.05 level of significance hence there is not any association between pretest and any demographic variable so that research hypothesis $\mathrm{H} 2$ is rejected.

Conclusion: Most of the rural secondary school girls had less knowledge regarding premenstrual syndrome so they need detail and thorough knowledge for premenstrual syndrome.

Keywords: Assess, Effectiveness, Information Booklet, Secondary School Girls, Premenstrual Syndrome. 


\section{INTRODUCTION:}

Adolescence or puberty is the transitional period linking childhood to adulthood and involves physical, biological \& psychosexual changes. Adolescence comes from the Latin word "adoloscere" which mean 'to come to maturity' comes the exact period when a normally puberty begins $\&$ end is not defined, but varies between the age of 13 and 16 years. ${ }^{1}$

WHO has defined adolescence a progression from appearance of secondary sexual characters to sexual and reproductive maturity and development of adult mental processes. ${ }^{1}$

Tanner \& Marshall described five stages of pubertal changes in a normal girl. These are in the following sequencePhysical growth, Development of secondary sex organs, breast development, Pubic \& axillary hair growth, Development of ovaries \& the genital organs, Growth spurt \& menstruation. The healthy adolescent population is considered as a social agent of change toward a population with a healthier life style. The period of adolescence for a girl is a period of physical and psychological preparation for safe motherhood. One of the major physiological changes that take place in adolescent girls is onset of menarche. 1
In a normal menstrual cycle, there is cyclic hormone production from the ovary with parallel proliferation of the uterine lining in preparation for implantation of the embryo. A normal menstrual cycle lasts 21 to 35 days with 2-6 days of flow and an average blood loss of 20-60 ml.2

$$
\text { Premenstrual syndrome is a }
$$
psychosomatic disorder of unknown etiology, often noticed just prior to menstruation. There is cyclic appearance of a large number. of symptoms during the last 7-10 days of the menstrual cycle. It should fulfill the following criteria, Not related to any organic lesions, regularly occurs during the luteal phase of each ovulatory menstrual cycle, Symptoms must be severe enough to disturb the life style of the woman or the women requires medical help, Symptom-free period during rest of the cycle.

Premenstrual syndrome can be broadly defined as any constellation of psychological and physical symptoms that reoccur regularly in the luteal phase of the menstrual cycle with or during menstruation and cause functional impairment. It is estimated that up to $85 \%$ of women who menstruate experience at least one premenstrual symptom, occurring within the two weeks before menses and easing after menstruation begins. ${ }^{3}$ 
For improving health adjustment the nurse helps the women \& her family by teaching following points this are teach possible causes of conditions \& treatment Teach relaxation techniques. Teach patient to do the following. Avoid stressful activities during premenstrual period. Fatigue, exaggerate symptoms, Take medication as prescribed, Reduce or eliminate consumption \& caffeine, Follow a regular exercise programme, Eat wellbalanced diet with adequate protein \& reduced intake of salts \&refined sugars Incorporate stress- reducing strategies into daily lifestyle, Increase intake of food high in vitamin B\& magnesium (green leafy vegetable, legumes, whole grain cereals). ${ }^{4}$

\section{OBJECTIVES OF THE STUDY}

1. To assess the pretest knowledge score of secondary school girls regarding premenstrual syndrome.

2. To administer information booklet to secondary school girls regarding premenstrual syndrome.

3. To assess the post test knowledge score of secondary school girls regarding premenstrual syndrome.

4. To compare pre test \& post test knowledge score of secondary school girls regarding premenstrual syndrome.

5. To find out the association of pretest knowledge score of secondary school girls regarding premenstrual syndrome with selected demographic variable.

\section{MATERIAL AND METHODS:}

The method adopted for the present study was evaluative approach as the study aimed at development of an intervention for assessing the knowledge of 120 secondary school girls in government secondary School dakan kotda at Udaipur this approach would help the investigator to evaluate the effect of specific interventions that is information booklet on the variable that is knowledge of secondary school girls regarding premenstrual syndrome in selected school at Udaipur in this study samples were drawn by using simple random sampling method data was collected by using structured knowledge questionnaire.

\section{RESULTS}

Table 13: Distribution of respondents by the level of knowledge $\mathbf{N}=\mathbf{1 2 0}$

\begin{tabular}{|c|c|c|c|}
\hline $\begin{array}{l}\text { LEVEL OF } \\
\text { KNOWLEDG } \\
\text { E }\end{array}$ & $\begin{array}{l}\text { SCOR } \\
\text { E }\end{array}$ & $\begin{array}{l}\text { PRETES } \\
T\end{array}$ & $\begin{array}{l}\text { POST } \\
\text {-TEST }\end{array}$ \\
\hline $\begin{array}{l}\text { Adequate } \\
\text { knowledge } \\
(75-100 \%)\end{array}$ & $0-12$ & $0 \%$ & $94 \%$ \\
\hline $\begin{array}{l}\text { Moderately } \\
\text { adequate } \\
\text { knowledge } \\
(50-75 \%)\end{array}$ & $13-18$ & $51 \%$ & $6 \%$ \\
\hline $\begin{array}{l}\text { Inadequate } \\
\text { Knowledge } \quad(0- \\
50 \%)\end{array}$ & $19-25$ & $49 \%$ & $0 \%$ \\
\hline Total & 25 & 100 & 100 \\
\hline
\end{tabular}


Table 1: The result showed that in the pretest none of the respondents had adequate knowledge on premenstrual syndrome, $51 \%$ respondents had moderately adequate knowledge \& $49 \%$ respondents had inadequate knowledge on premenstrual syndrome. After giving the information booklet, in the post test most of the respondents gain adequate knowledge on premenstrual syndrome that was 94\% whereas $6 \%$ respondents had moderately adequate knowledge \& no any respondents had inadequate knowledge on premenstrual syndrome.

\section{CONCLUSION:}

The conclusion of the study can be drawn in the following manners. Most of the rural secondary school girls had less knowledge regarding premenstrual syndrome so they need detail and thorough knowledge for premenstrual syndrome.

\section{REFERENCES}

1. Bourne\& Howkins et.al. Text book of gynecology. Elsevier Publisher;13thed .2004 p 49-50

2. Mudaliar \& Menon's. Clinical obstetrics. Universities press limited Publisher; 11th ed. 2005 p. 18

3. Dutta.D.C. Text book of gynecology, new central Book agency Publisher; 3rd ed. 2001 p 172-173

4. BasavanthappaB.T. Text book of midwifery\& reproductive health nursing. Jaypee brothers medical publisher; 1st ed.2006 p 723-724.

5. J Clin Diagn et.al. Menstrual Pattern among Unmarried Women from Northern India Sep 2013; 7(9): p1926-1929. 